\title{
The effects of ingesting a tribulus containing proprietary supplement with combined resistance training on strength, body composition, and hormonal changes in males
}

Fanny Oliver ${ }^{1 *}$, Kristin Dugan ${ }^{1}$, Mallory McAdams ${ }^{1}$, Caleb Woodall1', Morgan Lewing ${ }^{1}$, Andrew White ${ }^{1}$, Sara Roman ${ }^{1}$, Darryn Willoughby ${ }^{3}$, Colin Wilborn ${ }^{1,2}$, Lem Taylor ${ }^{1,2}$

From International Society of Sports Nutrition; 7th Annual ISSN Conference and Expo

Clearwater Beach, FL, USA. 24-26 June 2010

\section{Background}

To investigate the potential effects in males on body composition, muscular strength, and hormones of a proprietary tribulus fruit extract and vitamin/mineral blend in combination with a resistance training program.

\section{Methods}

Twenty-eight $(22 \pm 4.48$ yrs, $179.22 \pm 9.04 \mathrm{~cm}, 83.41 \pm 11.95$ $\mathrm{kg}, 15.90 \pm 5.07 \% \mathrm{BF}$ ) resistance-trained males between the ages of 18 and 30 were randomly assigned by body weight to ingest either a placebo or tribulus blend (tribulus fruit extract- $40 \%$ saponins) in a double-blind manner. Subjects participated in a supervised 4-day per week periodized resistance training program split into two upper and two lower extremity workout per week. At baseline (T1), 4 weeks (T2), and 8 weeks (T3), body composition (DEXA), muscular strength (1RM), muscular endurance, and anaerobic power measurements (Wingate) were determined. Venous blood samples were obtained using standard procedures at all time points. Blood analyses included serum and whole blood metabolic profile and the serum analysis of free testosterone, cortisol, and insulin were conducted using standard EIA and ELISA assay protocols. Statistical analyses utilized a two-way ANOVA with repeated measures for all dependent variables $(\mathrm{p}<0.05)$.

'Human Performance Laboratory, University of Mary Hardin-Baylor, Belton,

TX 76513, USA

Full list of author information is available at the end of the article

\section{Results}

Significant main effects for time $(p=0.001)$ were observed for the dependent variables bench press 1RM (T1: $106.10 \pm 16.41$ to T3: $112.91 \pm 22.23 \mathrm{~kg}$ ), leg press 1RM (T1: $333.73 \pm 57.36$ to T3: $441.5 \pm 52.59 \mathrm{~kg}$ ), and lean muscle mass (T1: $66.23 \pm 9.23$ to T3: $67.08 \pm 9.19 \mathrm{~kg}$ ) indicating that the resistance training protocol resulted in significant adaptations. However, no significant interactions were observed on the measures of strength and body composition $(\mathrm{p}>0.05)$ indicating that supplementation had no additional benefit. A significant main effect for time was observed for serum insulin ( $p=$ 0.01 ), however there was no significant differences between groups. No significant main effects or interactions $(p>0.05)$ were noted on measures of anaerobic power, muscular endurance, RHR \& BP, nutritional dietary intake, cortisol, free testosterone, or on the markers of the metabolic/CBC panel.

\section{Conclusion}

Supplementation of a tribulus and vitamin/mineral blend has no effect on the muscular strength and hypertrophy adaptations that occur with resistance training in this double-blinded, placebo controlled clinical trial. Additionally, supplementation had no significant impact on hormonal status and no clinical side effects were observed as indicated by the analysis of a full serum and whole blood metabolic profile. 


\section{Author details}

${ }^{1}$ Human Performance Laboratory, University of Mary Hardin-Baylor, Belton, TX 76513, USA . ${ }^{2}$ Exercise Biochemistry Laboratory, University of Mary Hardin-Baylor, Belton, TX 76513, USA . ${ }^{3}$ Exercise and Biochemical Nutrition Laboratory, Baylor University, Waco, TX 76798, USA.

Published: 15 September 2010

doi:10.1186/1550-2783-7-S1-P17

Cite this article as: Oliver et al:: The effects of ingesting a tribulus containing proprietary supplement with combined resistance training on strength, body composition, and hormonal changes in males.

Journal of the International Society of Sports Nutrition 2010 7(Suppl 1):P17.

Submit your next manuscript to BioMed Central and take full advantage of:

- Convenient online submission

- Thorough peer review

- No space constraints or color figure charges

- Immediate publication on acceptance

- Inclusion in PubMed, CAS, Scopus and Google Scholar

- Research which is freely available for redistribution

Submit your manuscript at www.biomedcentral.com/submit
C Biomed Central 